DOI:

\title{
РАЗВИТИЕ СПОСОБНОСТИ К ПРОИЗВОЛЬНОЙ САМОРЕГУЛЯЦИИ У СПОРТСМЕНОВ ИГРОВЫХ ВИДОВ СПОРТА
}

\section{DEVELOPMENT OF THE CAPACITY FOR VOLUNTARY SELF-REGULATION FOR THE SPORTSMEN OF PLAYING TYPES OF SPORT}

\author{
Светлана Соколовская, Анастасия Малькова \\ Национальный исследовательский Нижегородский \\ государственный университет имени Н. И. Лобачевского \\ kuzminasv2013@inbox.ru; malkowa.n@yandex.ru
}

\begin{abstract}
АННОТАЦИЯ
В данной работе представлено исследование развития способности к произвольной саморегуляции у спортсменов игровых видов спорта. Цель исследования - изучение особенностей психологической подготовки спортсменов и разработка программы развития способности к произвольной саморегуляции как основного психического навыка при подготовке к соревнованиям спортсменов-бадминтонистов, а также в процессе соревновательной борьбы.
\end{abstract}

Ключевые слова: психологическая подготовка спортсменов, саморегуляция, психологическая компетенция, игровые виды спорта.

Key words: psychological training of athletes, self-regulation, psychological competence, sports games.

Соревновательная деятельность требует от спортсмена полной отдачи, работы на пределе возможностей, создает ситуации, в которых спортсмену необходимо уметь быстро переключаться, анализировать и регулировать свое состояние. Особенностью игровых видов спорта являются сложные тактические действия, решение о которых необходимо 
принимать в считанные секунды. Именно поэтому важность психологической подготовки в игровых видах спорта трудно переоценить. Сегодня уровень физической и технической подготовки у ведущих спортсменов практически одинаков. Стабильно побеждают те, чей уровень контроля своих эмоций и психического состояния выше, т. е. те, кто лучше владеют приемами произвольной саморегуляции.

Произвольная саморегуляция - умения и навыки спортсменов преднамеренно, сознательно с помощью различных приемов и средств изменять свое поведение, физическое и эмоциональное состояние, формировать положительные эмоциональные отношения к выполнению упражнений, связанных с риском (Родионов 2005).

Современные научные представления о произвольной саморегуляции позволяют рассматривать ее как одну из составляющих в системе психологической подготовки спортсменов (Конопкин 2008).

Навык произвольной саморегуляции включает в себя ряд составляющих: эмоциональная соревновательная устойчивость, помехоустойчивость, стабильность, формирование которых требует преднамеренных усилий и времени, а значит, должны быть включены в комплексе общей многолетней подготовки спортсмена (Горячев 2012).

Уникальность данной работы заключается в том, что способность к произвольной саморегуляции рассматривается как определенная компетенция, т. е. комплекс знаний, умений, навыков и определенных качеств личности (см. рисунок 1). Данная компетенция должна формироваться в учебно-тренировочном процессе (Алексеев 2006).

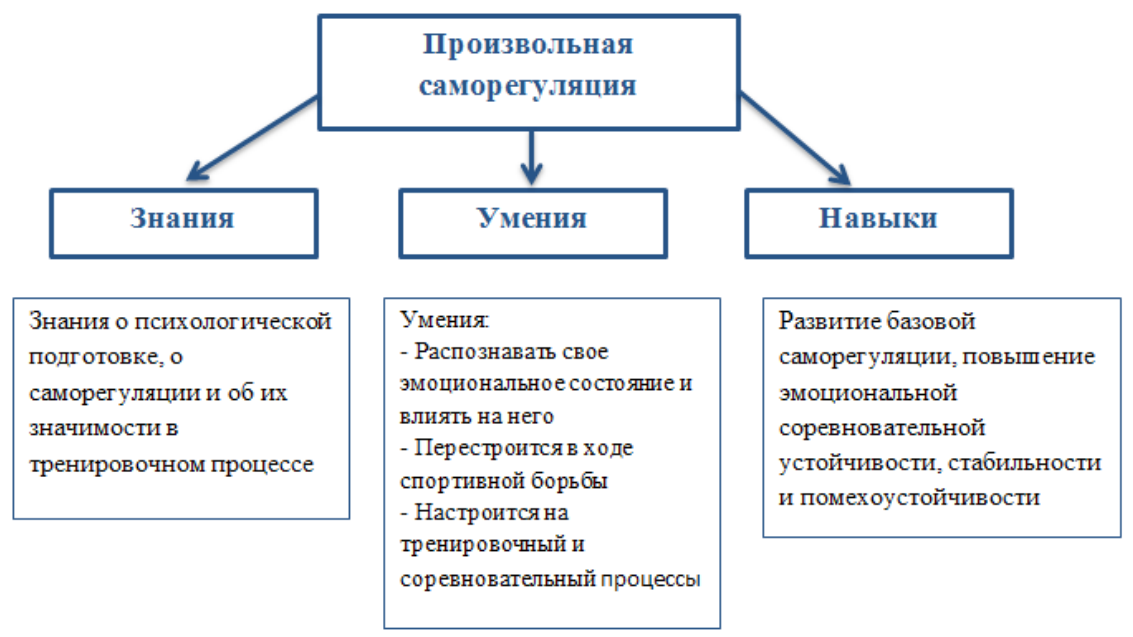

Рисунок 1. Схема понятия прочзвольная саморегуляция как компетенции 
Цель исследования, проведенного в Национальном исследовательском Нижегородском государственном университете им. Н. И. Лобачевского, - изучить уровень способности произвольной саморегуляции спортсменов игровых видов, составить и апробировать специальную программу психологической подготовки спортсменов игровых видов спорта.

В качестве диагностического инструментария в данной работе выбраны: тестирование для проверки уровня знаний о психологической подготовке и о приемах саморегуляции и анкета Вадима Эмильевича Мильмана для оценки уровня развития навыка произвольной саморегуляции.

Исследование проводилось на базе Нижегородской спортивной детско-юношеской школы олимпийского резерва по бадминтону. В нем принимали участие 50 спортсменов бадминтонистов в возрасте от 12 до 18 лет, все они имели спортивный разряд от 2-го взрослого до кандидата в мастера спорта. Результаты испытуемых в начале исследования показали достаточно низкий уровень знаний о психологической подготовке и приемах саморегуляции у спортсменов, а также низкие показатели умения регулировать свое эмоциональное состояние.

Как уже было сказано, наличие у спортсмена произвольной саморегуляции рассматривается нами как владение профессионально-личностной компетенцией. Исходя из этого, разработанная программа психологической подготовки включает в себя три этапа:

- ознакомительный этап, задачей которого является обогащение занимающихся необходимым знаниями о произвольной саморегуляции,

- подготовительный этап, направленный на формирование различных психологических умений: умения правильно оценивать свое эмоциональное состояние, умения влиять на него, умение управлять своими мыслями и чувствами,

- основной этап, цель которого - развитие навыка произвольной саморегуляции: повышение эмоциональной соревновательной устойчивости, стабильности и помехоустойчивости.

Продолжительность включения экспериментальной программы в учебно-тренировочный процесс составила 4 месяца.

На первом этапе проводились лекции и беседы на тему психологической подготовки, саморегуляции, их роли и функций, для повышения уровня знаний спортсменов. Данные беседы вызвали интерес у занимающихся, которые стали понимать значимость высокого уровня саморегуляции для достижения профессиональных успехов.

На втором этапе мы использовали различные психотехнические игры, направленные на развитие таких умений, как умение правильно 
оценивать свое эмоциональное состояние и умение влиять на него, управляя своими мыслями и чувствами, посредством словесных простейших самоприказов. Так же применялись простейшие методы саморегуляции: дыхательные практики, самоприказы, самоодобрение, самоубеждение и физические упражнения на растяжение мышц и на напряжение. Спортсмены отметили, что последними методами саморегуляции они уже пользовались, но при этом эффективность применения данных методов в комплексе с другими намного выше.

Цель третьего этапа подготовки - развитие навыка произвольной саморегуляции. На данном этапе было использовано обучение психорегулирующей тренировке Анатолия Васильевича Алексеева, являющимся эффективным комплексным методом произвольной саморегуляции (Алексеев 2006). Психорегулирующая тренировка (ПРТ) состоит из успокаивающей и мобилизующей частей. Успокаивающая часть ПРТ - вариант аутогенной тренировки, снижение уровня бодрствования. Мобилизующая часть тренировки обеспечивает приведение функций организма в состояние наивысшей готовности спортсмена к деятельности. Для проведения занятий психорегулирующей тренировки отводилось 10-20 минут. Стоит отметить, что формулы успокаивающей части ПРТ на первой недели приводили не к успокоению, а к возбуждению. Лишь в конце третьей недели занятий был достигнут успокаивающий эффект.

Контрольный эксперимент предполагал использование тех же диагностических методик, что и до проведения программы. Результаты эксперимента представлены в таблице 1.

Таблица 1. Сводные данные оценки уровня развития навыка произвольной саморегуляции до и после проведения программы по развитию способности к произвольной саморегуляции

\begin{tabular}{|c|c|c|c|c|c|c|}
\hline & 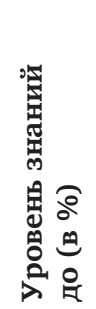 & 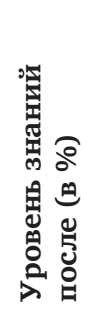 & 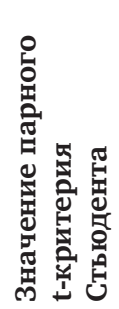 & 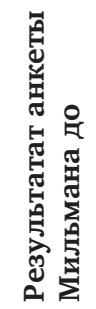 & 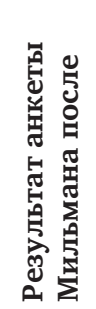 & 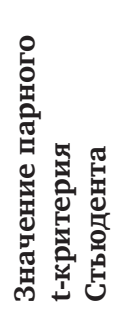 \\
\hline $\begin{array}{l}\text { Группа } \\
\text { исследуемых }\end{array}$ & 26,6 & 96,3 & 26,9 & $-3,1$ & $+3,0$ & 19,6 \\
\hline
\end{tabular}

После проведения программы по развитию способности к произвольной саморегуляции компоненты данной способности резко 
выросли, что повело за собой возможность улучшения спортивных результатов бадминтонистов. Установление корреляции развитой способности к произвольной саморегуляции и спортивных результатов следующий этап данного исследования.

Многие специалисты в области спортивной психологии, считают, что решение проблемы регуляции эмоциональных состояний позволит не только улучшить спортивные достижения, но и сохранить здоровье спортсмена, деятельность которого протекает в условиях жесткой конкуренции, больших физических и нервных нагрузок (Панкратов 2001).

\section{SUMMARY}

This paper presents a study of the development of arbitrary self-regulation in athletes of game sports. The aim of the research is to study the peculiarities of psychological training for athletes and to develop a programme aimed at the development of arbitrary self-regulation as the basic mental skill in preparation of Badminton players for competitions.

\section{ЛИТЕРАТУРА}

Алексеев 2006

Горячев, Ивашин 2012

Конопкин 2001

Панкратов 2001
Алексеев, А. В. (2006) Преодолей себя! Психическая подготовка в спорте. Москва: Феникс.

Горячев, А. П., Ивашин, А. А. (2012) Бадминтон. Примерная программа спортивной подготовки для ДЮСШ, СДЮШОР, УОР и ШВСМ. Москва: Советский спорт.

Конопкин, О. А. (2001) Осознанная саморегуляция как критерий субъектности. Вопросы психологии. Москва: Вопросы психологии, с. 22-34.

Панкратов, В. Н. (2001) Саморегулячия психического здоровья. Москва: Изд-во Института психотерапии. 